\title{
Silicificaciones selectivas en Thalassinoides y otras estructuras biogénicas asociadas a calizas de plataforma marina y hardground (Albiense inferior, Sonabia, Cantabria)
}

\author{
Selective silicification of Thalassinoides and other biogenic \\ structures in marine platform limestones and hardground \\ (Lower Albian, Sonabia, Cantabria)
}

\author{
M.A. Bustillo ${ }^{1}$, J. Elorza ${ }^{2}$, D. Díez-Canseco ${ }^{3}$ \\ 1 Departamento de Geología. Museo Nacional de Ciencias Naturales-CSIC, C/ José Gutiérrez Abascal 2, 28006 Madrid. \\ Email: abustillo@mncn.csic.es. ORCID ID: http://orcid.org/0000-0003-3626-4609 \\ 2 Departamento de Mineralogía y Petrología. Universidad del País Vasco, Apdo. 644; 48080 Bilbao. \\ Email: josejavier.elorza@ehu.es. ORCID ID: http://orcid.org/0000-0003-3735-9407 \\ 3 Departamento de Estratigrafía. Universidad Complutense de Madrid-IGEO, C/ José Antonio Novais 12, 28040 Madrid. \\ Email: daviniadiezcanseco@ucm.es. ORCID ID: http://orcid.org/0000-0002-6524-9291
}

\section{RESUMEN}

\begin{abstract}
El presente trabajo estudia los diferentes tipos de sílex que aparecen en la Formación Calizas de Oriñón (Aptiense superior-Albiense inferior), en un zona concreta de la costa oriental de Cantabria (Liendo-Castro Urdiales), debido a su gran abundancia y espectacularidad. Las rocas que los incluyen son principalmente biocalcarenitas (wackestones/packstones de pellets, fragmentos de equinodermos, ostreidos, foraminíferos y espículas calcáreas o silíceas calcificadas), siendo el ambiente de depósito marino de plataforma abierta, y existiendo un hardground regional, donde las silicificaciones son diferentes. La fuente de la sílice proviene de la calcitización o disolución de las espículas de esponjas silíceas.

Se determina que la gran mayoría de sílex (mosaicos de cuarzo micro-microcriptalino y calcedonita principalmente), se forman por la silicificación selectiva de estructuras biogénicas, siendo las galerías de Thalassinoides preferentemente silicificadas, debido a que en su relleno existe mayor proporción de materia orgánica y mayor porosidad y permeabilidad. En las calizas que soportan el hardground además de las silicificaciones selectivas sobre fósiles (rostros de belemnites, ostreidos y equínidos), la sílice se acumula de forma importante en huellas de alimentación y rellenos de perforaciones, dando lugar a su vez a costras sobre bioturbaciones y perforaciones que a pesar de su importancia no han podido ser clasificadas.

La silicificación de todas las estructuras biogénicas, originó inicialmente fases opalinas y tuvo lugar durante la diagénesis temprana cuando la oxidación de la materia orgánica estaba todavía activa, conservándose en los Thalassinoides silicificados formas (filamentos y cocoides) que podrían ser consideradas microbianas. La transformación ópalo-cuarzo fue temprana, preservándose dichas formas.

En las galerías silicificadas de Thalassinoides los procesos diagenéticos son diferentes a los de los sedimentos carbonáticos marinos que las incluyen, y al resto de estructuras biogénicas silicificadas, existiendo en estas galerías neoformación de dolomita y calcita, en un microambiente cerrado donde las condiciones cambian de
\end{abstract} oxidantes a reductoras.

Recibido el 25 de octubre de 2016 / Aceptado el 8 de febrero de 2017 / Publicado online el xx de mayo de 2017

Citation / Cómo citar este artículo: M.A. Bustillo, J. Elorza \& D. Díez-Canseco (2017). Silicificaciones selectivas en Thalassinoides y otras estructuras biogénicas asociadas a calizas de plataforma marina y hardground (Albiense inferior, Sonabia, Cantabria). Estudios Geológicos 73(1): e064. http://dx.doi.org/10.3989/egeol.42668.435.

Copyright: (c) 2017 CSIC. This is an open-access article distributed under the terms of the Creative Commons Attribution-Non Commercial (by-nc) Spain 3.0 License. 
Palabras clave: sílex; Thalassinoides; diagénesis confinada; estructuras biogénicas; hardground.

\section{ABSTRACT}

In this work different types of chert from the Oriñón Limestone Formation (upper Aptian-lower Albian) are studied. This formation outcrops in the eastern coast of Cantabria (Liendo-Castro Urdiales area) and includes outstanding and abundant cherty nodules, lenticular layers and crusts. The host rock is mainly a biocalcarenite (wackestone/packstone) of pellets, echinoids fragments, oysters, foraminifers and calcareous or calcified siliceous sponge spicules. The Oriñón Limestone Formation was deposited in a marine open-shelf environment and preserves a hardground of regional extent with particular chert crusts. The silica source is associated to the dissolution of siliceous sponge spicules or to their calcification.

Most of the chert is constituted by mosaics of micro-cryptocrystalline quartz and calcedonite, and it is generated by the selective silicification of biogenic structures, mainly dwelling trace fossils (Thalassinoides isp.) because of the higher amount of organic matter and the higher porosity and permeability of the burrow infill. In the hardground, selective silicification affects body fossils such as belemnites, oysters and echinoids, and trace fossils (feeding burrows and borings) where in addition cherts is accumulated as an indeterminate crust.

The silicification of the biogenic structures firstly occurred in form of opaline phases during the early diagenesis while the oxidation of the organic matter was active. Thus, Thalassinoides trace fossils affected by silicification preserve filaments and cocoids that might have had a microbial origin.

Neoformation of dolomite and calcite occur only within the Thalassinoides trace fossils which indicates that diagenetic processes taking place within these burrows differed from those affecting the host rock and other biogenic structures. Dwelling trace fossils would have supposed a close micro-environment where the oxidation conditions changed from high to low rate.

Keywords: chert; Thalassinoides; confined diagenesis; biogenic structures; hardground.

\section{Introducción}

El sílex, en sus variados tipos, formas y texturas cristalinas, es frecuente encontrarlo en las potentes sucesiones de depósitos carbonatados, generados en distintos ambientes marinos del Mesozoico y Cenozoico en la Cuenca Vasco Cantábrica. A pesar de la relativa abundancia, visibilidad y fácil reconocimiento, bajo el punto de vista petrológico se le sigue prestando una atención mínima. En trabajos generales regionales, su existencia es ignorada o simplemente citada como "presencia de nódulos de sílex". Con el objetivo de salvar esta falta de conocimiento, durante las últimas décadas del siglo pasado, fueron estudiados los procesos de silicificación que se produjeron en materiales carbonatados del Cretácico Superior en la citada Cuenca Vasco Cantábrica. Así, se prestó atención a los diferentes tipos de silicificaciones tempranas y tardías, controladas por la configuración en tramos de la Secuencia de Bouma (Tb, Tc y Td), en las turbiditas carbonatadas de ambientes profundos en el Arco Vasco (Elorza \& Bustillo, 1989). También fueron objeto de atención, siempre en materiales del Cretácico Superior, las silicificaciones producidas por reemplazamiento selectivo en las galerías de tipo Thalassinoides registrados en materiales más someros de la plataforma carbonatada norcastellana
(Elorza \& García-Garmilla, 1993; 1997 y GarcíaGarmilla \& Elorza, 1996). Además, dado el interés del sílex como materia prima utilizada en los tiempos prehistóricos, se ha prestado un notable interés en su caracterización, aprovechamiento y fuentes de aprovisionamiento a partir de los diferentes yacimientos paleolíticos estudiados en la Cuenca Vasco Cantábrica y Pirineo navarro (Elorza, 1992; Tarriño, 2001; Tarriño et al., 2015).

La presencia de sílex es conocida también en las plataformas carbonatadas del Cretácico Inferior, específicamente en el complejo Urgoniano (Aptiense-Albiense) de la costa oriental de Cantabria (Rosales, 1995; Aranburu, 1998), pero su estudio no ha sido abordado en profundidad. En este trabajo se plantea la caracterización de diferentes sílex en la Fm. Calizas de Oriñón (Aptiense superior-Albiense inferior), en un zona concreta de la costa Cantábrica, entre Castro Urdiales y Liendo (Sonabia) (Fig.1) porque en ella los sílex destacan por su abundancia y espectacularidad. En esta zona concurren dos circunstancias singulares: a) una alta proliferación de burrows y otras trazas de actividad orgánica que se silicifican preferencialmente, y por lo tanto, se preservan de una forma excepcional y b) la presencia de un hardground regional (Rosales, 1995) en el que también se localizan diferentes tipos de 

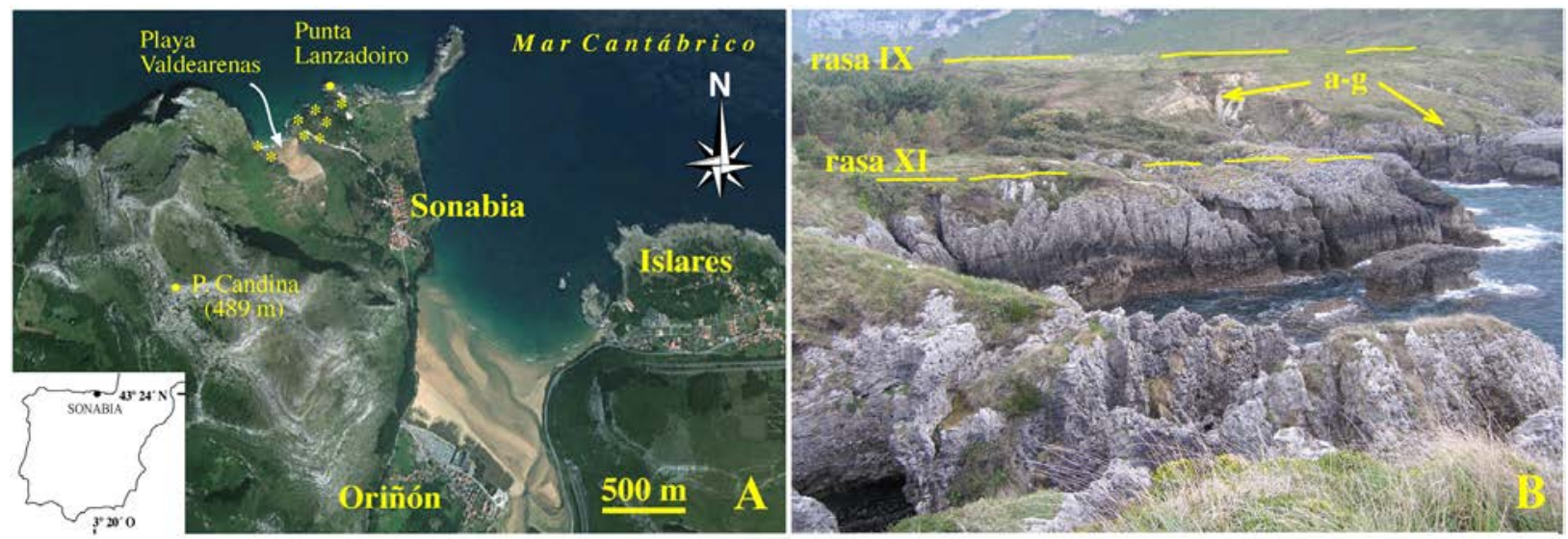

Fig. 1.-Localización de la sección estudiada. A. Vista aérea de la zona costera con la playa de Valdearenas y Punta Lanzadoiro (Liendo-Sonabia, Cantabria). Los afloramientos estudiados, pertenecientes a la Fm. Calizas de Oriñón, quedan remarcados con amarillos; B. Aspecto de los acantilados de calizas urgonianas con una gran profusión de nódulos de sílex. Es visible la fuerte karstificación con relleno de arenas-gravas amarillentas (a-g), además de varias rasas marinas (IX y XI) de abrasión cuaternaria.

silicificaciones. Es objetivo de este trabajo establecer las causas que provocan la extraordinaria abundancia de sílex, considerando su localización sobre las estructuras biogénicas dominantes y sus características petrológicas. Se pretende determinar la fuente de la sílice y los mecanismos genéticos de formación de sílex, lo que implica el seguimiento de una diagénesis confinada relacionada con procesos biológicos, la cual es diferente de la diagénesis general sufrida por enterramiento de los depósitos carbonatados.

\section{Contexto geográfico y geológico}

La serie estudiada se localiza en los municipios de Castro Urdiales y Liendo (parte oriental de Cantabria). Olivé Davó \& Ramírez del Pozo (1982) en la Hoja Geológica ${ }^{\circ} 36$ (Castro Urdiales), muestran que una falla normal pone en contacto las calizas masivas que conforman la Peña Candina (489 m) en la zona occidental, asignadas a "Calizas con rudistas y orbitolinas" (litología $\mathrm{n}^{\circ} 7$ en el mapa) de edad Aptiense medio - Albiense inferior, con las calizas dispuestas en la zona oriental de la playa de Valdearenas (Punta Lanzadoiro) denominadas "Calizas arcillosas con espículas" (asignadas con el $n^{\circ} 8$ ) de edad Albiense medio-Cenomaniense inferior y con buzamientos de $15^{\circ}-30^{\circ}$ al Sureste (Fig. 1A). Estas últimas calizas son más tableadas y presentan rasgos de estilolitización y abundantes nódulos de sílex, que sobresalen de la masa caliza por su mayor resistencia a la disolución.
Todo el conjunto litológico mencionado pertenece a las calizas en facies Urgonianas (Aptiense-Albiense) que se desarrollan en la Cuenca Vasco Cantábrica y han sido plegadas por la orogenia Alpina, contribuyendo también a su disposición actual los movimientos halocinéticos de las sales del Keüper, visibles más al Oeste (Playas de San Julián y Laredo).

Más recientemente, Rosales $(1995,1999)$ delimita las edades de las potentes masas de calizas aflorantes y establece que durante el Albiense inferior se produjo, mediante fallas distensivas sinsedimentarias, la compartimentación del área en surcos (Sonabia, Allendelagua, Cotolino-Ontón y Somorrostro) cada vez más profundos hacia oriente y paleoaltos calizos emergidos como los de Candina, Cerredo y Arenillas. La Fm. Calizas de Oriñón (Aptiense superior a Albiense inferior), se genera en un ambiente de plataforma abierta, alcanzando $480 \mathrm{~m}$ de potencia, en el corte específico de Oriñón y 460 m en Pico Candina más a occidente. De acuerdo con Rosales (1995), esta formación está constituida en su parte superior por calizas bioclásticas con abundantes nódulos de sílex que constituye la llamada Secuencia Deposicional 5 (SD 5). Esta secuencia queda seccionada por una superficie de erosión y se pone en contacto con los materiales suprayacentes del surco de Sonabia. El hardground formado sobre el límite de secuencia (E1), presenta una intensa bioturbación y perforaciones, concentración de rostros de belemnites, e incrustación de serpúlidos y ostreidos. Los 
rellenos del surco de Sonabia están constituidos por una serie (S1), generada en un ambiente estuarino relativamente profundo, conformado por calcarenitas margosas con esponjas, calcarenitas bioclásticas de grano grueso interestratificadas con margas (calcarenitas con laminación ondulada, wavy), y calcarenitas limosas, de grano fino con estratificación ondulada, hasta llegar a su parte final con diez episodios de niveles de resedimentación, denominados D1-D10. Todo el conjunto de resedimentación supera los 50 metros de potencia. Es en las calizas bioclásticas pertenecientes a SD 5 y en las calcarenitas de la zona basal del relleno del surco de Sonabia, donde se han generado los nódulos de sílex que son motivo de este trabajo.

Las calizas con nódulos de sílex quedan ampliamente expuestas en la Punta Lanzadoiro (zona oriental de la Playa de Valdearenas) (Fig. 1A) a favor de varias superficies subhorizontales de abrasión marina (rasas) emergidas durante el Cuaternario (Fig. 1B). Así, la rasa más baja a 7-8 m sobre el nivel actual del mar, parece ser equivalente a las reconocidas más al Oeste por Mary (1983) de edad Eemiense (MIS 5e) y denominada por Flor \& Flor Blanco (2014) rasa XI, mientras que la superior a unos $40 \mathrm{~m}$ pudiera corresponder a la rasa IX de estos mismo autores. Ambas rasas están intensamente desmanteladas por la karstificación posterior y parcialmente rellenas por depósitos de arenas-gravas amarillentas de naturaleza silícea, habiendo sufrido una completa descalcificación.

\section{Metodología}

Se tomaron muestras de los diferentes tipos de sílex que se observan en la columna, y sus rocas caja. El estudio mineralógico se llevó acabo con Difracción de Rayos X (DRX), mediante diagramas de polvo total, utilizando un Equipo PHILIPS modelo PW1710, equipado con monocromador de grafito. Mediante micro-Raman, utilizando un microscopio confocal con espectrómetro Thermo Fisher DXR, se determinó la mineralogía puntual sobre cristales específicos.

El estudio petrológico fue realizado por microscopía óptica convencional y electrónica de barrido (MEB). En MEB, se trabajó sobre fragmentos de muestras metalizadas con oro, con un equipo FEI
Inspect, realizándose a la vez análisis químicos puntuales por energía dispersiva (EDS), con un equipo OXFORD Inca. Todos los instrumentos utilizados pertenecen al Museo Nacional de Ciencias Naturales (CSIC) de Madrid.

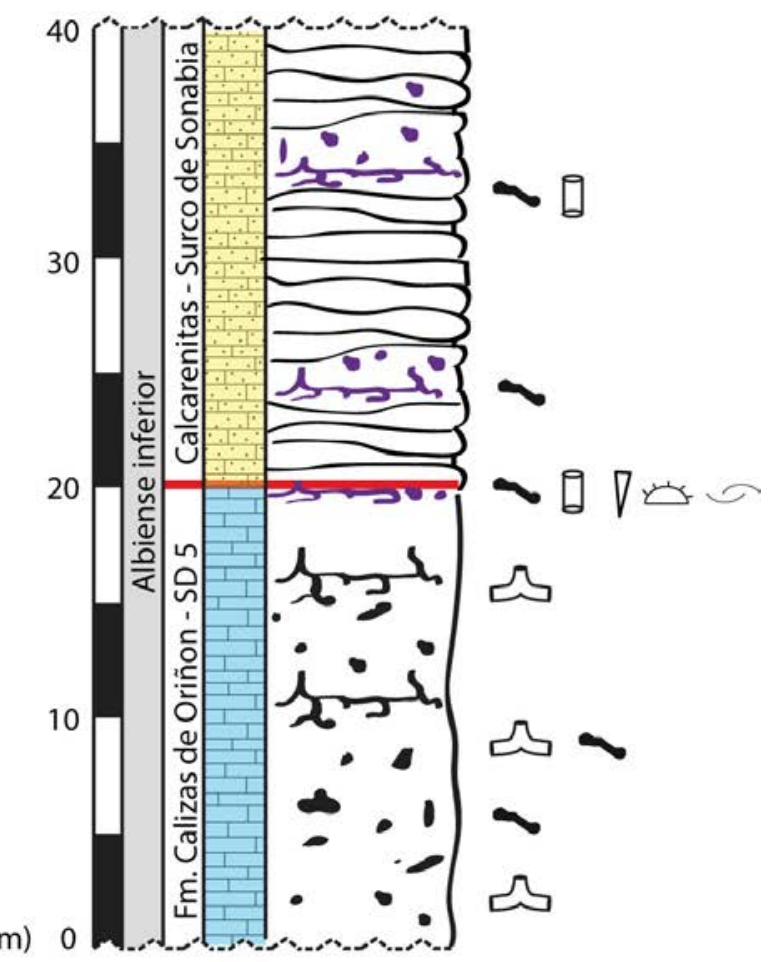

LITOLOGIAS

Silex en costras

Sílex en nódulos

Grainstone con estratificación ondulada y hummocky?

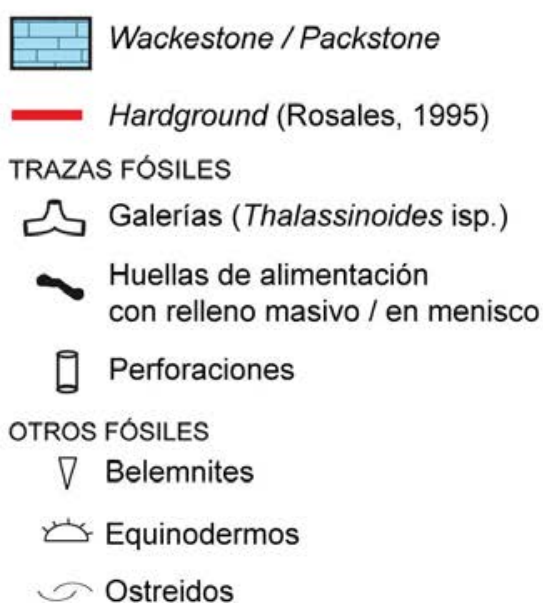

Fig. 2.-Columna litológica de la sección estudiada. Las unidades y terminología han sido tomadas de Rosales (1995). 


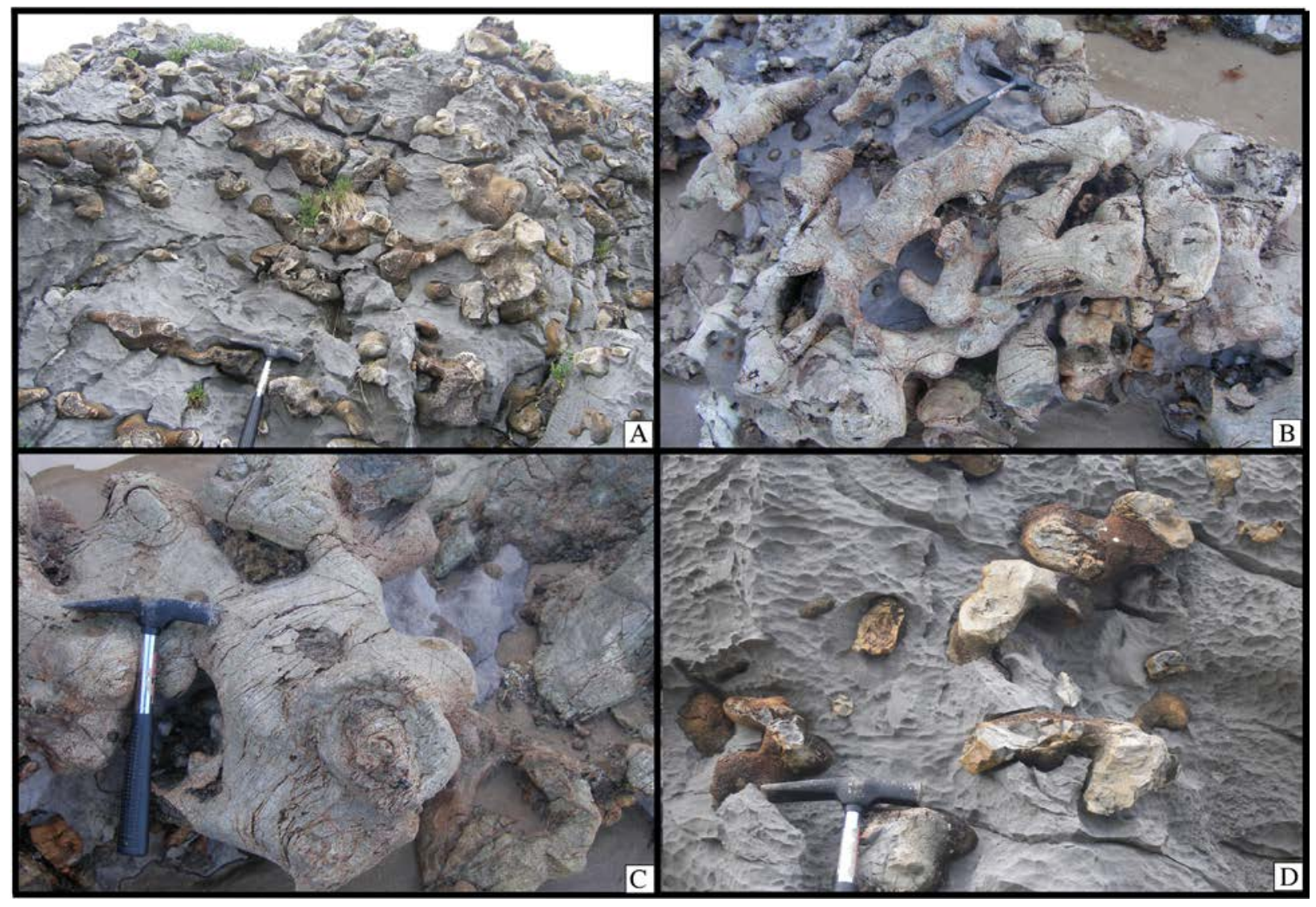

Fig. 3.-Sílex en Thalassinoides. A. Entramado de galerías de Thalassinoides interconectadas, donde se aprecia las formas originales y su desarrollo preferentemente horizontal. Las galerías han sido resaltadas y protegidas por la silicificación; B. Nótese la intensa disolución sufrida por la caliza urgoniana (Fm. Calizas de Oriñón), mientras que las galerías silicificadas mantienen sus formas originales remarcadas por una pátina externa rojiza de óxidos de hierro; C. Detalle de algunas secciones transversales de las galerías donde se observa una estructura concéntrica; D. Formas nodulosas correspondientes a secciones de galerías; se aprecia el color claro del interior del sílex frente a la pátina rojiza de óxidos de hierro de la superficie de contacto con la roca caja. El mango de la piqueta mide $28 \mathrm{~cm}$.

\section{Estructuras biogénicas y sílex}

Para nuestro estudio nos hemos ceñido a una sección litológica de aproximadamente $40 \mathrm{~m}$ (Fig. 2) que engloba la parte superior de las calizas bioclásticas de la Fm. Calizas de Oriñón $(\approx 20 \mathrm{~m})$, el hardground (E1) que las limita, y además la base de la serie superior formada por las calcarenitas pertenecientes al llamado surco de Sonabia $(\approx 20 \mathrm{~m})$. En base a las características morfológicas de los nódulos y zonas silicificadas se definen los siguientes tipos:

\section{Galerías de tipo Thalassinoides}

Se reconocen profusamente en la parte alta de la Fm. Calizas de Oriñón (Fig. 2). Los sílex se localizan en trazas que constituyen un sistema de galerías con ramificaciones a la misma altura, amplio desarrollo en la horizontal, alguna comunicación vertical (shafts) a diferentes alturas, ensanchamientos notables en las intersecciones (turnarounds) y terminaciones bruscas en forma de saco (cul de sac) (Figs. 3A y B). Esta configuración de las excavaciones junto con la ausencia de ornamentación en sus paredes, son características del icnogénero Thalassinoides. Los diámetros de las galerías varían entre 5-10 cm y las longitudes observadas en planta pueden alcanzar el metro. La silicificación se ciñe a las galerías, remarcando sus paredes con una pátina rojiza (óxidos de hierro) respecto a la roca caja gris. Los sílex formados son compactos, con su superficie exterior neta y lisa, pero suele estar fracturada, 
y en alguna ocasión se observan pequeños desplazamientos (Figs. 3B y C). En sección transversal, pueden tener un anillo diferenciado o varios, generando estructuras concéntricas de diferentes grosores
(Fig. 3C). Aquellas galerías que son subparalelas a la estratificación, quedan un poco aplanadas por compactación, presentando secciones ovoidales, con su eje mayor acorde con el plano de estratificación. En

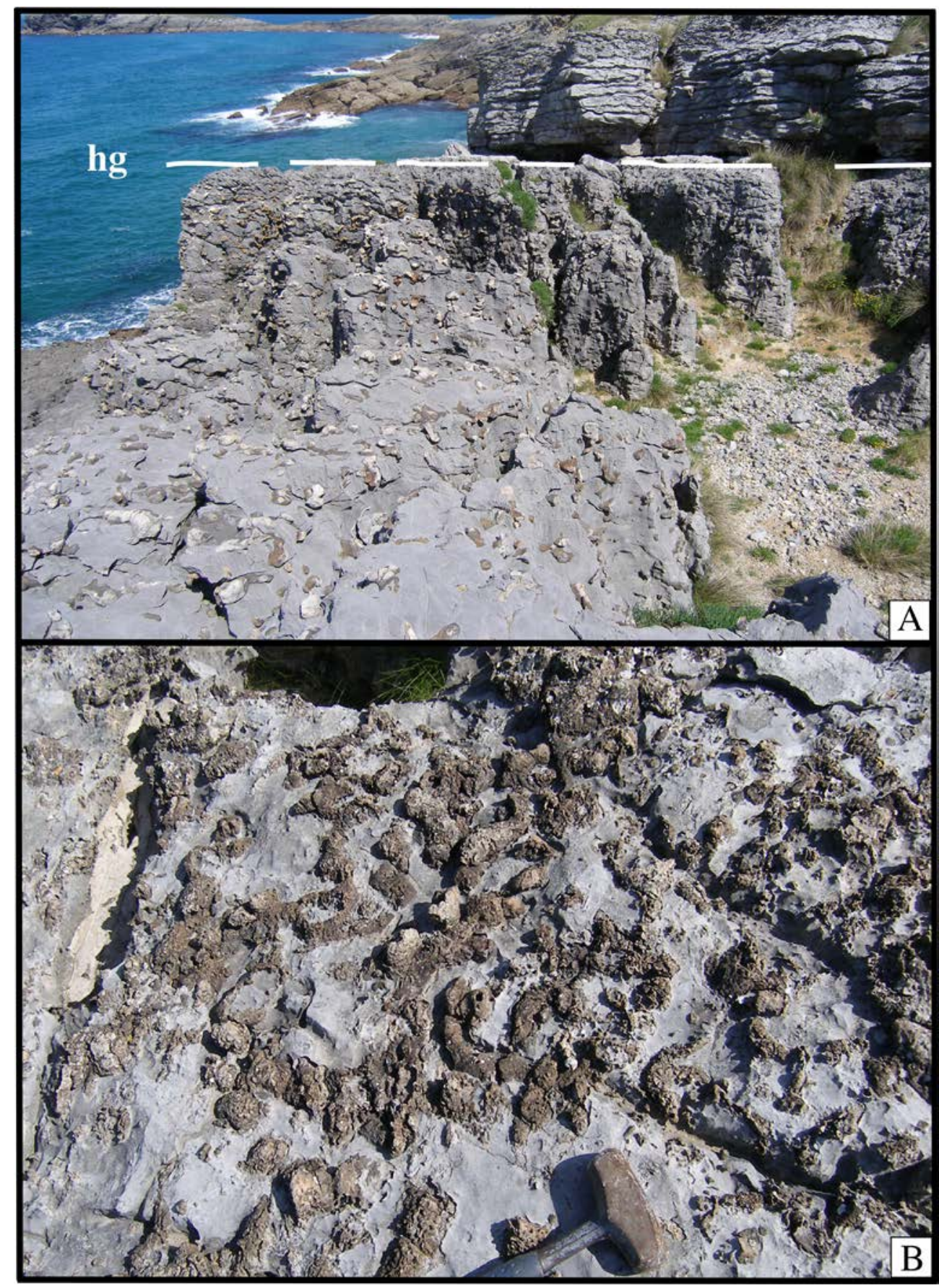

Fig. 4.-Parte superior de la Fm. Calizas de Oriñón y hardground. A. Aspecto general de la caliza urgoniana con las galerías de Thalassinoides silicificadas, la cual está limitada a techo por la presencia de una superficie rectilínea correspondiente al hardground (hg). Por encima se aprecian las calcarenitas de la base del relleno del "surco de Sonabia"; B. Aspecto de la superficie de hardground (hg), con estructuras biogénicas parcialmente silicificadas, en tonos rojizos, generando una costra irregular. 
secciones subverticales de la columna litológica no es reconocible el trazado de las galerías, y solamente son perceptibles las formas nodulosas más o menos alargadas (Fig. 3D) que ocasionalmente están conectadas en diferentes planos de estratificación.

\section{Estructuras biogénicas asociadas al "hardground"}

La superficie que conforma el hardground (Figs. 4A y B) incluye diferentes bioturbaciones y perforaciones silicificadas que son objeto de estudio, además de serpúlidos, rostros de belemnites, ostreidos y equínidos que no serán considerados. Se diferencian:

\section{a) Huellas de alimentación}

Pueden aparecer en cualquier punto de la sección litológica, además de en el hardground. Presentan formas tubulares, sinuosas, sin ramificaciones y con secciones circulares de diámetro menor de $0,5 \mathrm{~cm}$. Este tipo de trazas han sido observadas interfiriendo con otros sistemas de galerías en dos situaciones: 1) la traza se localiza afectando a la pared o al relleno de una galería previamente constituida, formando una traza compuesta (galería-huella tubular) y 2) la traza fue generada previamente y es cortada por la galería. En ambas situaciones, las huellas tubulares estarían asociadas a un comportamiento de alimentación. Este comportamiento es sugerido en la primera situación, por el carácter compuesto de la traza (galería-huella tubular) que indicaría una reutilización por parte de los organismos de un sustrato con mayor contenido orgánico, p.ej. el que constituye la pared de la galería. En la segunda situación, la asignación de estas trazas a huellas de alimentación es indicada por el relleno activo y estructurado en meniscos que está típicamente asociado con la manipulación del sedimento por parte de los organismos, incluyendo la ingestión (p.ej. Bown \& Kraus, 1983).

b) Estructuras biogénicas sin discernir marcadas por costras silíceas

En el hardground, se localizan numerosos sílex que a pesar de su apariencia no han podido ser claramente definidos como trazas fósiles. Estos sílex también aparecen en menor proporción en las areniscas carbonáticas superiores correspondientes al relleno del surco de Sonabía (Fig. 2). Tienen formas muy irregulares, presentando a veces apariencia de galerías. Sobre el plano del hardground (Fig. 4B), parece dominar la forma de tubo sinuosoidal de 5-7 cm de altura y hasta $10 \mathrm{~cm}$ de anchura. Destacan por presentar frecuentemente un exterior silíceo oqueroso donde los tabiques tienen a su vez una porosidad que le da aspecto reticulado milimétrico. Existe una disolución selectiva de la caliza frente al sílex que deja huecos en el interior de estos nódulos lo que pone de manifiesto que solo esta silicificado el exterior (alrededor de $1 \mathrm{~cm}$ ), por lo que se pueden considerar costras silíceas envolventes, con cierto enraizamiento hacia el interior (Figs. 5A, B y C). Ocasionalmente se observan dentro de las costras huellas de alimentación de pequeños organismos, y perforaciones (Fig. 5C). La distribución y forma aleatoria de las costras no permite determinar que esta silicificación esté adscrita a una traza o estructura determinada.

c) Estructuras de bioerosión (perforaciones)

Dentro de zonas irregulares silicificadas en el hardground se diferencian perforaciones que muestran secciones cilíndricas (Fig. 5C), un contacto neto y un relleno con colores rojizos, negros, etc., que difiere del substrato silicificado que las alberga. Son tubos con secciones de diámetros entre 0.5 y $1 \mathrm{~cm}$, y que suelen tener a su alrededor halos más claros, estando silicificado todo el conjunto.

\section{Mineralogía y Petrología}

\section{Thalassinoides silicificados}

La roca caja que incluye los sílex de Thalassinoides es una biocalcarenita (wackestones/packstones) que además de los aloquímicos presentan micrita y cementos de esparita (Figs. 6A y B). Como aloquímicos aparecen fundamentalmente pellets y bioclastos pertenecientes a fragmentos de placas de equinodermos, ostreidos, foraminíferos y espículas calcáreas o silíceas calcificadas. Pueden aparecer inclusiones opacas dispersas atribuibles a óxidos de $\mathrm{Fe}$, pero son escasas. Los cementos de esparita rellenan pequeñas porosidades y forman también recrecimientos sintaxiales sobre las placas de equinodermos, entre otros. El ambiente de depósito sería marino de plataforma abierta (Rosales, 1995). 


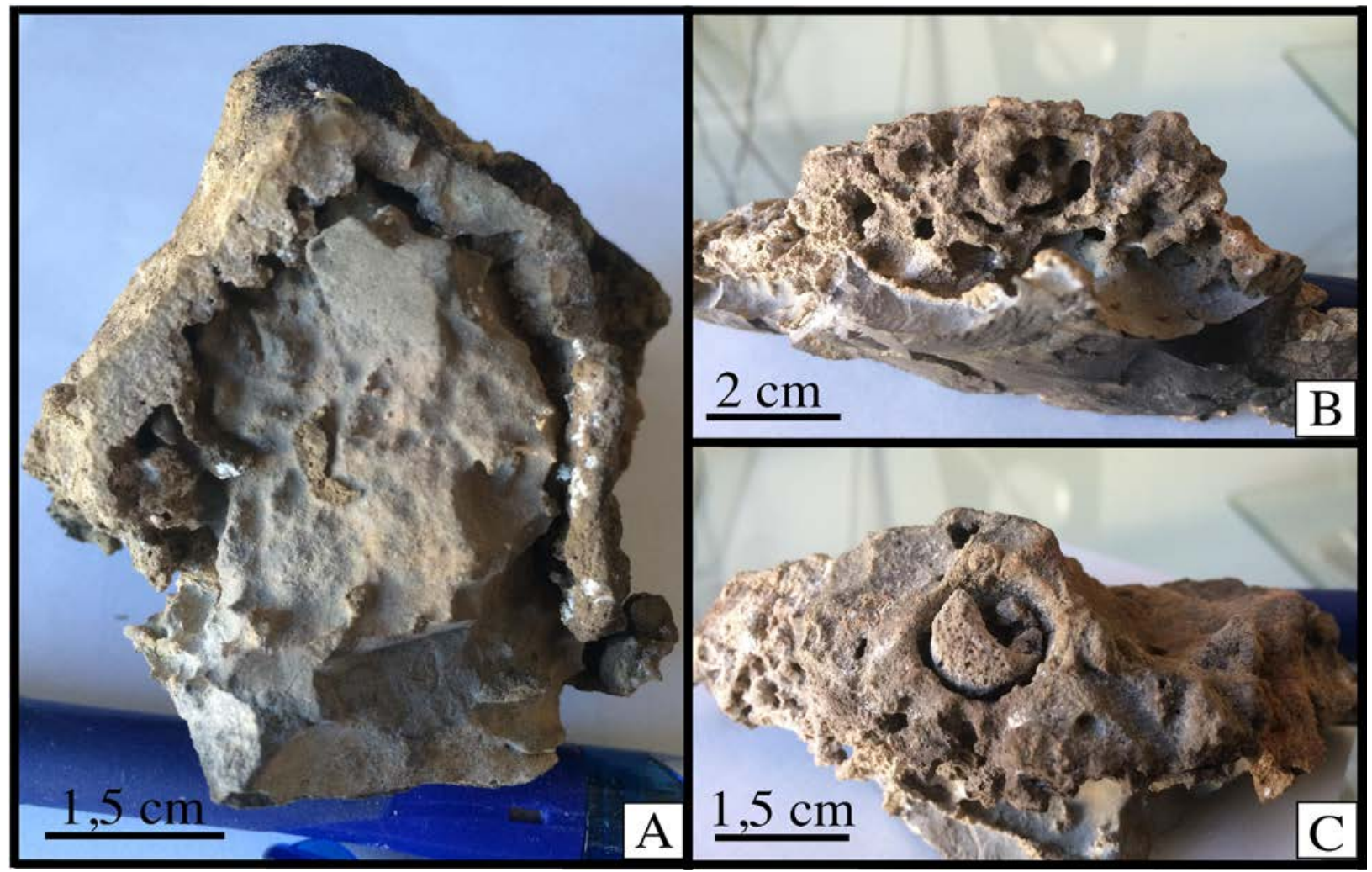

Fig. 5.-Costras silíceas asociadas al hardground. A. Sección de la costra silícea sobre la calcarenita, mostrando un enraizamiento hacia el interior; B. Superficie de la costra silícea con aspecto oqueroso; C. Vista en planta de una perforación subvertical dentro de la costra silícea.

Los sílex de Thalassinoides están constituidos por: 1) diferentes texturas de cuarzo, 2) relictos carbonáticos (bioclastos) sin silicificar correspondientes al relleno de la galería, 3) inclusiones de minerales opacos ferruginosos y 4) cristales neoformados de calcita y dolomita. En DRX, se detecta que la proporción de cuarzo varía entre el 80 y $90 \%$, no apareciendo actualmente fases opalinas primitivas. Presentan numerosas microgrietas, frecuentemente aislando intraclastos poligonales que no se observan en la roca caja. El entramado general está formado por mosaicos de cuarzo micro y criptocristalino (Figs. 6A y B), existiendo además calcedonita (textura fibrosa de elongación negativa) como consecuencia de la silicificación de los microfósiles y de los cementos de calcita, y como resultado del relleno de huecos. Solo puntualmente y muy escasamente se observaron texturas fibrosas de elongación positiva (cuarcina/lutecita) en la silicificación de algún bioclasto específico. Las inclusiones opacas ferruginosas, responsables de los tonos amarillentos en nícoles paralelos (Fig. 6A) son muy abundantes estando distribuidas dispersas por todo el entramado silíceo. Los relictos carbonáticos que quedan dentro de la galería silicificada, como testigos del relleno inicial por sedimento carbonático, son preferentemente aloquímicos y cementos constituidos por cristales de esparita, no apareciendo pellets ni otros componentes micríticos que se observan abundantemente en la roca caja. Es frecuente encontrar dentro de la galería silicificada cristales de calcita (corroborado con tinción de alizarina y análisis por micro-Raman), con secciones rómbicas y tamaño entre 200 y $400 \mu \mathrm{m}$ (puntualmente hasta $700 \mu \mathrm{m}$ ), que pueden presentar los lados irregulares, sin terminar completamente (Fig. 6C). Se interpreta que son cristales neoformados posteriormente a la silicificación general porque se sobreimponen a las texturas y fábrica del sílex y no aparecen en la roca caja. A pesar de ser posteriores, algunos cristales neoformados de calcita se 


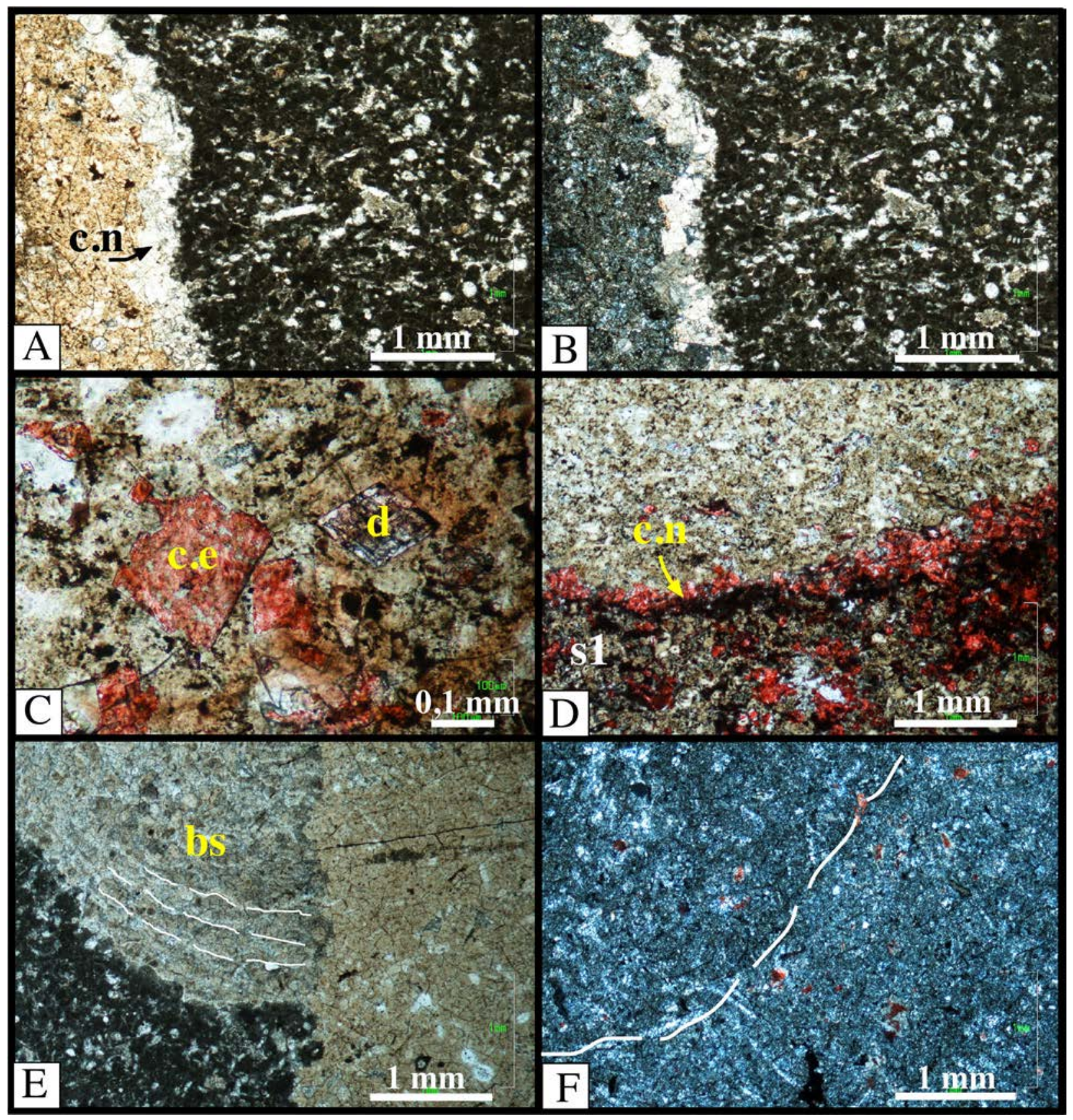

Fig. 6.-Características petrográficas de los sílex formados en galerías de Thalassinoides. A. Galería silicificada (parte izquierda de la foto) en contacto con la roca caja de caliza (parte derecha de la foto). La galería silicificada, presenta tonos marrones y está constituida principalmente por mosaicos de cuarzo micro-criptocristalinos, minerales opacos (óxidos de Fe) y muestra numerosas microgrietas. La roca caja es una biocalcarenita en la que destacan bioclastos, entre otros de espículas de esponjas, y pellets fecales (wackestone-packstone). La zona de contacto queda remarcada por grandes cristales de calcita neoformada (c.n). Nícoles paralelos; B. Ídem con Nícoles cruzados; C. Detalle de cristales neoformados de dolomita (d) y calcita espática (c.e) (teñida en rojo con alizarina), incluidos en el sílex de la galería. El cristal de calcita tiene bordes incompletos, y dentro de él hay zonas silíceas que destacan por no estar teñidas. Nícoles paralelos; D. Galería silicificada en contacto con una aureola exterior de caliza parcialmente silicificada (s1) (parte inferior de la foto). Nótese el film micrítico propio de la pared de Thalassinoides y la calcita neoformada (c.n) (teñida con alizarina) del borde de la galería. Nícoles paralelos. E. Sección de Thalassinoides (parte derecha de la foto) sobreimpuesta a una huella de alimentación (bs), ambas silicificadas. Obsérvese la estructura interna de láminas en menisco (líneas discontinuas blancas) del relleno de la huella, y la biocalcarenita (parte inferior izquierda). Nícoles cruzados; F. Vista en sección de la estructura concéntrica de ciertas galería silicificadas, y que es consecuencia de una mayor 0 menor proporción de cuarzo micro-criptocristalino o impurezas. El límite entre anillos es señalado por la línea discontinua blanca. 
encuentran puntualmente reemplazados por cuarzo indicando que durante la diagénesis se dan pequeños reemplazamientos reversibles calcita-sílice. Por otra parte, las galerías silicificadas están atravesadas por grietas que se rellenan de calcita o cuarzo, lo cual confirma que el sílex alcanza un comportamiento frágil, existiendo una movilidad más tardía de carbonatos y sílice en disoluciones que cementan grietas. Los cristales euhedrales de calcita neoformados (c.e) pueden aparecen dispersos por todo el entramado silicificado de la galería y además en las zonas de contacto con la roca caja (Figs. 6A y B), siendo en este caso su crecimiento siempre hacia la galería silicificada. Se identifican también sobreimpuestos a la textura y fábrica del sílex, cristales euhedrales no teñidos, con secciones rómbicas y bordes oxidados que corresponden a dolomita (d) (corroborado por micro-Raman) (Fig. 6C). Presentan mayor relieve y menor tamaño (hasta $120 \mu \mathrm{m}$ ) que los cristales de calcita espática (c.e), siendo escasos $(<3 \%$ en sección, y no en todas). Cuando los cristales rómbicos están completamente oxidados se pueden interpretar como dedolomita.

El exterior de la excavación, en su contacto con la roca caja carbonatada, es nítido e irregular, con microentrantes y microsalientes. En ocasiones se observa un borde micrítico que es atribuido al film micrítico típico de las paredes de las galerías asignadas a Thalassinoides (p.ej. Buatois \& Mángano, 2011) (Fig. 6D). Cuando interfieren huellas de alimentación con Thalassinoides, ambos silicificados, los límites se siguen claramente identificando (Fig. 6E).

Las galerías silicificadas pueden presentar zonas concéntricas, observables a simple vista (Fig. 3C). En unos casos se observa en el exterior una sola envuelta, y en otros las zonas concéntricas se extienden por toda la bioturbación. Cuando existe una sola envuelta podría interpretarse que la silicificación afectó primeramente a la galería y luego creció hacia el exterior afectando a la roca caja, dando lugar a un anillo exterior con bastantes relictos de ella. Los restos de la pared de la galería, y la calcita neoformada (c.n) en la zona de contacto sirven para diferenciar la galería propiamente dicha de la aureola exterior parcialmente silicificada (S1) (Fig. 6D). En las galerías donde es visible la presencia de anillos concéntricos únicamente se puede diferenciar anillos más isótropos de otros menos, por tener los más isótropos una mayor concentración de cuarzo criptocristalino o más impurezas (Fig. 6F).

\section{Huellas de alimentación silicificadas}

Estas trazas quedan afectadas por silicificaciones menos intensas que la de las galerías de Thalassinoides, dejando muchos relictos de carbonatos, y trasluciéndose la sedimentación en menisco (Fig. 6E). Los sílex muestran texturas de cuarzo semejantes a las de Thalassinoides (mosaicos de cuarzo micro-criptocristalino y calcedonita), aunque contienen menos microgrumos de opacos ferruginosos y los cristales de carbonatos neoformados no existen. Estas huellas, pueden ser cortadas por galerías posteriores (Fig. 6E).

\section{Costras silíceas de aspecto reticulado}

La roca caja que incluye estas estructuras silicificadas corresponde a una grainstone-packstone, y suele estar cercana al hardground. Como aloquímicos se observan mayoritariamente espículas de esponjas calcáreas o calcitizadas (Figs. 7A y B), existiendo también pellets, micro-foraminíferos y placas de equinodermos, estando los aloquímicos frecuentemente micritizados. Las espículas de esponjas son muy abundantes, y a veces de gran tamaño, siendo esto la diferencia más clara con la roca caja que incluye Thalassinoides silicificados.

Los sílex presentan contornos muy irregulares en su contacto con la roca caja. Están constituidos por mosaicos de cuarzo micro-criptocristalino y calcedonita (Figs. 7A y B), y aunque puede tener inclusiones de opacos ferruginosos, estos son menos abundantes que en las galerías silicificadas de Thalassinoides. No se observan carbonatos neoformados, o se observan mal. Incluyen relictos de la roca caja y ocasionalmente presentan espículas silíceas y restos de esponjas.

\section{Perforaciones y bioturbaciones silicificadas en zonas del "hardground"}

Las perforaciones y bioturbaciones silicificadas del hardground están formadas por cuarzo criptocristalino, y ocasionalmente calcedonita. A pesar de estar más intensamente silicificadas que el substrato 


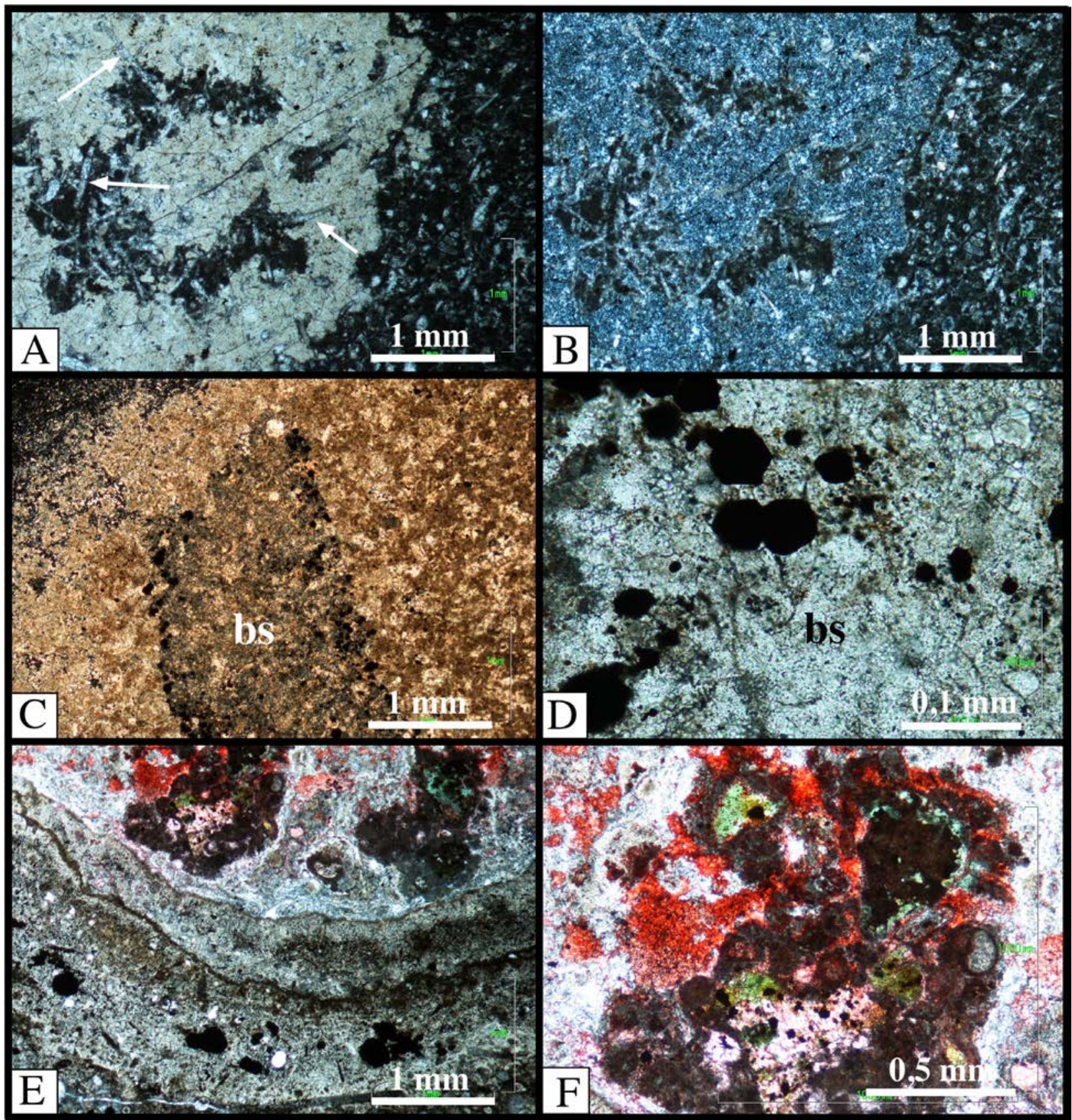

Fig. 7.-Características petrográficas de los sílex formados sobre diferentes estructuras biogénicas asociadas al hardground. A. Costra silícea en contacto con la roca caja. El sílex (parte izquierda de la foto) está constituido por mosaicos de cuarzo microcriptocristalino, y mantiene muchos relictos de roca caja, destacando las espículas de esponja silíceas, señaladas por las flechas blancas. Nícoles paralelos; B. Ídem con Nícoles cruzados; C. Sección longitudinal de una bioturbación silicificada (bs), constituida por cuarzo criptocristalino prácticamente isótropo, con relictos carbonáticos sin silicificar. El borde de la bioturbación con respecto a la roca caja carbonatada queda marcado por la presencia de formas poligonales de óxidos de Fe (magnetita?). Nícoles cruzados; D. Detalle de formas idiomorfas de óxidos de Fe incluidos en la bioturbación silicificada (bs). Nícoles paralelos; E. Sección transversal de una perforación rellena silicificada, observándose la parte central y las aureolas exteriores. En la parte central, entre los mosaicos del cuarzo micro-criptocristalino, se detectan relictos del relleno de la perforación junto a carbonatos neoformados (teñidos en rojo con alizarina) y glauconita en verde. Las formas poligonales de los óxidos de Fe se observan en las aureolas exteriores. Nícoles paralelos; F. Detalle de la zona central de la Fig. 7E. Nícoles paralelos. 


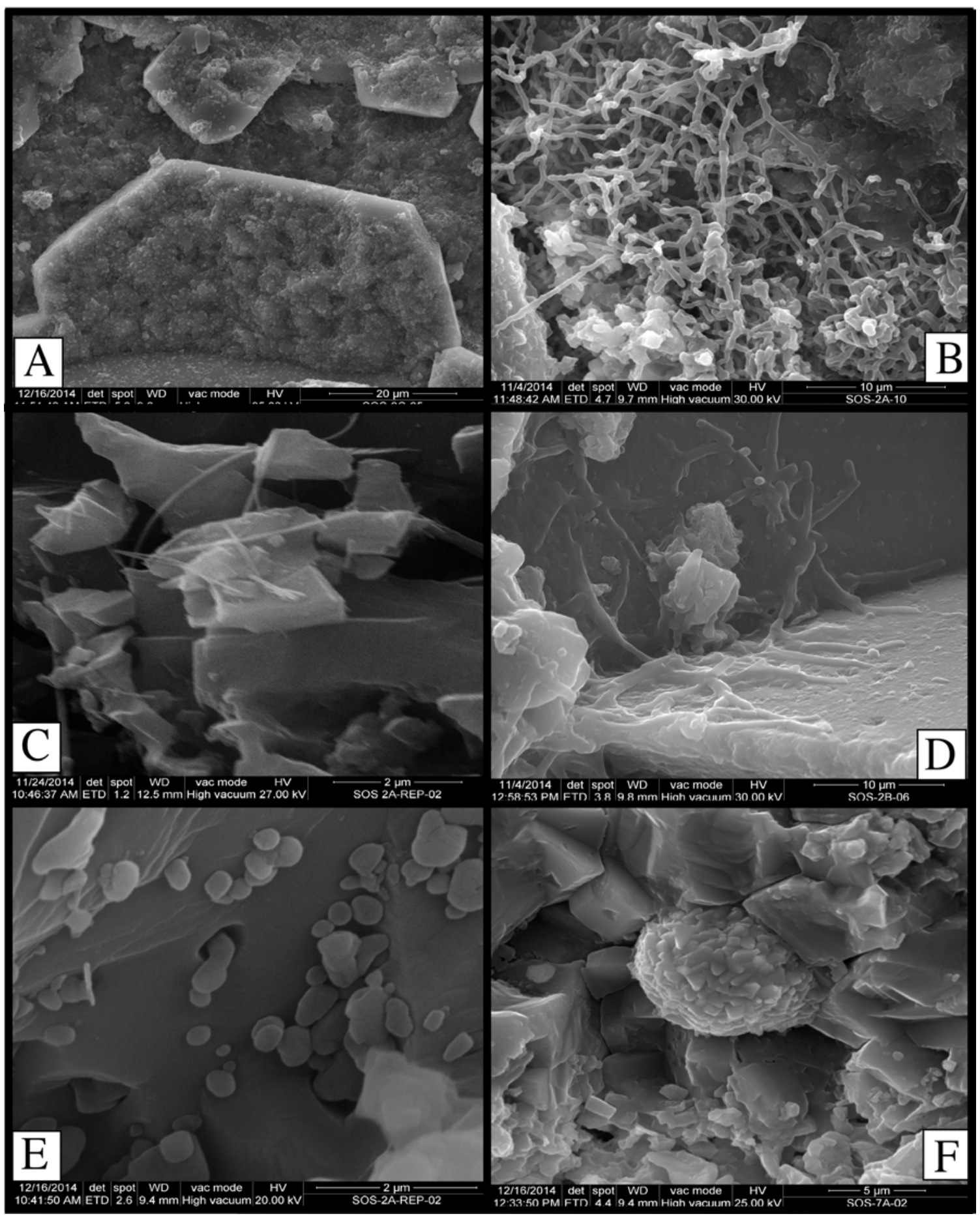

Fig. 8.-Aspectos en el Microscopio Electrónico de Barrido de las galerías de Thalassinoides y otras estructuras biogénicas silicificadas. A. Cristales de calcita neoformados en el interior de una galería de Thalassinoides. Los cristales de calcita crecen en un entramado de microesferas de sílice que también aparecen dentro de los cristales. Su borde exterior es muy compacto; B. Agrupaciones de formas filamentosas en el interior de una galería silicificada de Thalassinoides; C. Formas filamentosas entre cristales de calcita neoformada en una galería silicificada de Thalassinoides; D. Formas filamentosas sobre las superficies de cristales de cuarzo que forman el Thalassinoides silicificado. Se observa claramente como los filamentos están unidos con el cristal de cuarzo; E. Microesferas (cocoides silicificados?) incluidas en un cristal de calcita neoformada dentro de un Thalassinoides silicificado; F. Agregado de cristales de óxido de hierro (magnetita framboidal?) en una perforación rellena y silicificada del hardground. 
circundante, conservan muchos relictos de lo que fue el relleno carbonático. En sus paredes y en su parte exterior se pueden localizar secciones poligonales opacas oxidadas (Fig. 7C). Las secciones oxidadas son cuadrangulares $\mathrm{o}$, hexagonales, o bien una acumulación de ellas, con un tamaño entre 100 y 300 $\mathrm{m} \mu$ (Fig. 7D).

En las secciones transversales de ciertas perforaciones (Fig. 5C) las formas oxidadas se observan en halos interiores del tubo pero cerca del exterior (Fig. 7E). De acuerdo con los datos de Micro-Raman pueden corresponder a piritas y calcopiritas oxidadas, que se acompañan de hematites y magnetita. Localmente en la parte central de algunas perforaciones silicificadas existen zonas de tonos verdes asignadas a cementos o reemplazamientos de glauconita (Fig. 7F).

\section{Aspectos reconocidos en MEB en las silicificaciones de Thalassinoides y perforaciones}

El entramado general de cuarzo, que forma actualmente el relleno de las galerías, exhibe en MEB estructura de microesferas, lo que puede denotar un precursor opalino. Los análisis generales realizados a la matriz silícea registran además de la presencia de Si mayoritario un alto porcentaje en $\mathrm{C}$, sin que aparezca $\mathrm{Ca}$ (u otros elementos), lo que indicaría que puede existir materia orgánica en el entramado silíceo.

Los grandes cristales neoformados de calcita (Fig. 8A) contienen, en ocasiones, proporciones variables de $\mathrm{Mg}$, y siempre reflejan algo de contenido en $\mathrm{Si}$, consecuencia de que engloban y/o están recubiertos por microesferas de sílice. En ocasiones los cristales neoformados de calcita pueden tener un borde exterior más compacto (Fig. 8A) debido a la presencia de una película exterior de sílice rica en Fe. Localmente se han observado pequeñas microestalactitas de sílice, señalando que durante la diagénesis hay sílice que se disuelve y reprecipita.

Puntualmente en el entramado silíceo o sobre cristales de calcita de la pared de Thalassinoides pueden aparecer estructuras filamentosas (Figs. 8B, C y D) que podrían ser atribuidas a bacterias u hongos silicificados. Las formas filamentosas localmente aparecen claramente unidas a los cristales de cuarzo (Fig. 8D). También se han encontrado formas ovoidales, que podrían ser consideradas bacterias (bastones o cocoides) (Fig. 8E). Estas aparecen englobadas en los cristales de calcita, pudiendo deducirse que atacan a los cristales produciendo una porosidad esférica. Localmente también se detectan precipitados de óxidos de Mn.

En las perforaciones silicificadas asociadas al hardground, se observa en MEB con EDX, que además de calcita existe ankerita. Entre los carbonatos se identifican películas de óxidos de Fe y de sílice; puntualmente se encontraron microesferas de cristales de magnetita (Fig. 8 F), en las que además de Fe y $\mathrm{O}$, existe $\mathrm{C}$.

\section{Discusión}

La Fm. Calizas de Oriñón incluye numerosas trazas fósiles que han sido conservadas debido a que sufrieron procesos de silicificación. Por sus características morfológicas se diferencian Thalassinoides, huellas de alimentación, perforaciones, y otras estructuras biogénicas situadas próximas al hardground que no han podido ser asignadas a trazas conocidas. El mayor número de nódulos de sílex, que destacan por su gran profusión, está localizado sobre Thalassinoides, siendo las otras huellas más escasas, aunque cerca del hardground son también muy abundantes.

En toda la Fm. Calizas de Oriñón se observa la presencia de espículas carbonáticas y/o silíceas calcitizadas. Las espículas silíceas habrían sido la fuente de la sílice para todas las silicificaciones estudiadas, como es frecuente en los nódulos de sílex formados en las calizas de las plataformas marinas del Mesozoico (Maliva \& Siever, 1989). La fauna de esponjas silíceas durante el Cretácico es muy abundante y diversa, siendo el Albiense uno de los pisos donde adquieren mayor variación lateral (Zimmerle, 1991). Además, durante el Aptiense-Albiense, la Cuenca Vasco-Cantábrica sufre una tectónica activa extensional con una fuerte compartimentación en bloques debida a la apertura del Atlantico Norte (Rosales, 1995,1999), que permite una actividad hidrotermal reflejada más al sur por mineralizaciones de $\mathrm{Fe}-\mathrm{Pb}-\mathrm{Zn}$ de carácter estratiforme y más 
tardíamente asociados a fracturas, donde además se presenta en el encajante sílex bandeado y una silicificación hidrotermal (Herrero, 1989). Los aportes de sílice al medio marino sin duda potenciaron la proliferación de esponjas silíceas.

La silicificación preferente de las bioturbaciones es achacada a la presencia de materia orgánica, ya que esta ejerce un papel importante como fijador de la sílice (Knoll, 1985; Bustillo, 2010; entre otros). La gran cantidad de bioturbaciones en el tramo estudiado de las calizas de Oriñón, hace que la sílice proveniente de la disolución o calcitización de las espículas silíceas, y que sucede frecuentemente en la diagénesis temprana (Bak et al., 2015), no se pierda en el fluido intersticial del sedimento, sino que se quede fijada en las bioturbaciones originándose gran cantidad de nódulos de sílex.

\section{Silicificación y otros procesos diagenéticos en Thalassinoides}

Thalassinoides es una traza común de crustáceos decápodos en sucesiones marinas. Se interpreta generalmente como estructura combinada de habitación (Dominichia) y de alimentación (Fodinichia). El icnogénero Thalassinoides está caracterizado por presentar galerías de paredes lisas, excavadas en un fango calcáreo todavía blando, pero suficientemente cohesivo que no necesita reforzamiento. La disposición geométrica de su estructura está controlada por el gradiente energético y la tasa de sedimentación dominante, por lo que en áreas estables de plataforma y de cuenca con una baja energía, las galerías tienden a adoptar una geometría con un predominio horizontal, donde las conexiones verticales (shafts) con la superficie del sedimento son cortas y el conjunto de la estructura se dispone a muy poca distancia por debajo de la interfase agua-sedimento (García-Ramos et al., 1989). En las galerías de tipo Thalassinoides de la Fm. Calizas de Oriñón se conserva sobre todo el trazado horizontal (Fig. 3), como corresponde a las galerías formadas en áreas estables de plataforma abierta y de cuenca con baja energía.

Los procesos de silicificación de Thalassinoides, es un hecho conocido y estudiado en las formaciones cretácicas de Europa central (Clayton, 1986; Bromley \& Ekdale, 1984; Mortimore \& Pomerol, 1987). En la Fm. Calizas de Oriñón, en la mayoría de los casos la silicificación se ciñe principalmente a la galería, acabando en sus paredes. En general se admite que esto es consecuencia de la diferencia de porosidad entre la roca y el relleno de la traza (Bromley \& Ekdale, 1984). Los datos petrográficos comparativos entre el sílex y la caliza circundante indican que las partes micríticas y los pellets micríticos de la roca caja no aparecen como relictos dentro de los mosaicos de cuarzo micro-criptocristalino y las calcedonitas de la galería silicificada. Esto podría indicar que hubo una silicificación preferente de los componentes micríticos, o que el relleno de la galería, antes de silicificarse ya no tenía estos componentes. Esta segunda posibilidad es más factible porque el relleno de las galerías de tipo Thalassinoides, abiertas al exterior, suele contrastar con el substrato circundante (selección de partículas, tamaño de grano, composición etc.), dado que es introducido gravitacionalmente en la galería en un evento de sedimentación posterior. La falta de micrita en este relleno implicaría mayor porosidad. Los bivalvos, espículas y otros elementos elongados manifiestan una posición aleatoria en el relleno de las galerías, no existiendo orientación en relación a las paredes.

En ocasiones los sílex de Thalassinoides presentan un anillo exterior diferenciado de unos 5-10 mm. Los datos petrográficos señalan que este anillo se localiza en la roca circundante, a continuación de la pared de la galería demostrando que corresponde a una ampliación hacia el exterior de la zona silicificada. Estas ampliaciones pueden conseguir que se silicifiquen en conjunto otras trazas asociadas a Thalassinoides marcando la existencia de trazas compuestas. Se deduce que la formación de este anillo solo sucede en aquellos casos en que no hay grandes diferencias de porosidad entre la traza y la roca circundante. Clayton (1986) considera que ciertos anillos exteriores pueden corresponder al delgado film de sedimento que reviste la pared de Thalassinoides, pero en el caso estudiado es demasiado grueso. Esta aureola exterior no debe confundirse con la estructura interna concéntrica que se observa en algunas galerías silicificadas, y que corresponde a fenómenos inorgánicos de difusión en anillos, que se pueden dar durante las silicificaciones por efecto de impurezas iónicas (McBride et al., 1999).

En la génesis de las trazas del icnogénero Thalassinoides participan procesos biológicos y 
diagenéticos. El relleno inicial de las galerías puede sufrir procesos diagenéticos siendo frecuentes los reemplazamientos de los carbonatos del relleno por sílice, calcita o dolomita (Zijlstra, 1987; Mángano \& Buatois, 1994; Corlett \& Jones, 2012). Bromley \& Ekdale (1984), consideran que la silicificación preferencial de Thalassinoides frente a otras estructuras de bioturbación, es debido a la alta concentración de materia orgánica en el relleno (detritus orgánicos que entran con el bombeo del agua de mar, mucus de la pared de la galería, pellets fecales y otros residuos orgánicos acumulados por el carácter permanente de las galerías) y a la alta porosidad y permeabilidad (relleno pasivo no compactado manteniéndose a una profundidad relativamente alta bajo el fondo marino).

En las galerías de Thalassinoides de la Fm. Calizas de Oriñón, los procesos diagenéticos son muy importantes, existiendo reemplazamientos y neoformaciones a diferentes escalas. A gran escala, primero sufrieron silicificación y después carbonatación con neoformación de calcita y puntualmente dolomita, como lo demuestra el hecho de que estos carbonatos aparecen sobreimpuestos a la textura y fabrica del relleno silicificado. Las primeras fases silíceas consecuencia de la silicificación fueron opalinas como lo demuestran la gran presencia de cuarzo micro-criptocristalino y su microestuctura de microesferas en MEB (Bustillo, 2010). La materia orgánica habría facilitado la silicificación temprana opalina, quedando relictos de materia orgánica fijada a la sílice, y que incluso perdura hasta la actualidad, ya que se detecta $C$ por EDX en el entramado silíceo. La morfologías de filamentos y ovoides encontradas en MEB (Figs. 8B, C, D y E), señalan que pudo haber influencia microbiana. Zijlstra (1987) señala la importancia de los procesos de oxidación-reducción y el metabolismo bacteriano en la precipitación de la sílice. Se interpreta además que la silicificación general fue temprana porque las galerías están poco afectadas por la compactación y porque se han conservado signos de actividad microbiana. La transformación ópalo-cuarzo habría sucedido durante la diagénesis temprana, ya que el sílex formado como consecuencia de esta transformación se comporta frágil ante la compactación general y responde generando microgrietas. Las fracturas generales más grandes, que se observan a simple vista atravesando los nódulos, se formarían más tardíamente porque atraviesan las microgrietas. En ellas calcita y sílice tardía vuelve a precipitar.

La neoformación de calcita, y puntualmente dolomita, está restringida a la bioturbación silicificada y no se observan en las biocalcarenitas de la roca caja, donde el ambiente general sería oxidante. Bustillo \& Ruiz Ortiz (1987), consideran que posiblemente las neoformaciones de carbonatos idiomorfos en zonas silicificadas tienen lugar cuando la sílice está en fase opalina. La gran cantidad de microesferas de sílice incluidas en los cristales de calcita neoformados lo atestiguaría en este caso (Fig. 8A). Los bordes idiomorfos de los cristales de calcita y dolomita es explicado como consecuencia del mecanismo llamado "force of crystallization" (Maliva \& Siever, 1988). Estas ideas fueron seguidas por Mínguez \& Elorza (1994) y Erkiaga et al. (1997), para explicar la presencia de rombos de dolomita y calcita en determinados ejemplos de silicificaciones en carbonatos del Cretácico Superior en la Cuenca Vasco Cantábrica. La neoformación de carbonatos es consecuencia de una diagénesis confinada dentro de la bioturbación silicificada, porque este proceso no sucede en la roca carbonática circundante, como sucede en otros nódulos de sílex del Cretácico Superior de la región Vasco Cantábrica (Erkiaga et al., 1997). La formación de calcita y dolomita se facilitaría en la galería por varias causas, siendo esencial el incremento de porosidad y permeabilidad durante la diagénesis temprana debido a la degradación de la materia orgánica allí existente (Gingras et al., 2004).

En las galerías de tipo Thalassinoides de la Fm. Calizas de Oriñón, calcita y dolomita coexisten, pero al no interferir los cristales no es posible establecer relaciones temporales entre ellos. La calcitización es el proceso principal ya que los rombos de dolomita y dedolomita son muy escasos. En la literatura los reemplazamientos reversibles calcita-sílice han sido explicados por cambios en el pH (Siever, 1962; Bustillo, 2010, entre otros), siendo en pH alcalinos cuando se disuelve el ópalo y precipita la calcita. Corlett \& Jones (2012), señalan diferentes ambientes en excavaciones cementados por calcita o por dolomita. La calcita neoformada se produciría en condiciones suboxidantes y con poca materia orgánica marina, mientras que la dolomita se formaría en ambiente reductor. El paso de condiciones oxidantes a condiciones disaeróbicas dentro de las galerías se 
acompaña por la actividad de microorganismos fermentantes cuyos subproductos facilitan la dolomitización (Gingras et al., 2004). La formación puntual de dolomita tendría lugar en microambientes alcalinos, con procesos bacterianos y ambiente sulfato reductor, tal y como se aduce en la literatura general (Baldermann et al., 2015, entre otros) y todo ello asociado a la degradación de la materia orgánica. Los cambios químicos en el microambiente alrededor de la célula bacteriana y sus EPS, junto con la alta salinidad, tienen un papel esencial en la precipitación de dolomita, ya sea como soporte o como catalizador (Zhang et al., 2015, entre otros). Los óxidos de Fe son una constante dentro de Thalassinoides silicificados, y los cambios en el grado de oxidación del Fe, también influirían en el microambiente.

\section{Silicificaciones asociadas al "hardground"}

Huellas de alimentación, estructuras biogénicas sin discernir y perforaciones se encuentran preferentemente silicificadas en ciertas zonas del hardground (hg, Fig. 5), aunque las huellas de alimentación aparecen a lo largo de toda la columna, y las bioestructuras sin discernir también en los sedimentos superiores al hardground. En todos los casos se interpreta que la silicificación estaría fomentada por la presencia de materia orgánica.

Las más frecuentes son las estructuras biogénicas sin discernir formadas por costras silíceas centimétricas. Su morfología exterior reticulada podría recordar a las estructuras arrugadas que Dai et al. (2015) interpretan como tapices microbianos. Sin embargo, dado que estas costras presentan espesor centimétrico, tendría que observarse alguna estructura laminada en su interior, y ésta no aparece. Las características petrológicas de las costras, no revelan ningún componente silíceo claramente diferente a los componentes de la roca caja, por lo que no se puede interpretar su estructura como una estructura espicular de esponja silícea, a pesar de que las espículas silíceas son abundantes y acompañan a los aloquímicos carbonáticos tanto en la roca caja como en la costra silícea. La estructura interna de las costras, enraizándose en la roca carbonática, y su aspecto reticulado, podrían recordar a perforaciones en fragmentos biogénicos del hardground carbonático, tal y como exponen Taylor \& Wilson (2003) y
Bromley \& Schönberg (2008). Estos últimos autores consideran que las perforaciones de esponjas pueden conservarse mejor que su estructura espicular. La perforación se rellenaría por el sedimento carbonático circundante que incorporaría también espículas silíceas. Posteriormente este relleno se silicificaría preferentemente debido a la presencia de la materia orgánica, que habría dejado la bioerosión.

Por otra parte, las costras silíceas remarcan morfologías que podrían recordar a galerías. Estas galerías habrían sido silicificadas solo en sus paredes y zonas circundantes por presentar allí mayor proporción de materia orgánica, quedando la mayoría del relleno carbonático de la galería sin silicificar.

En el hardground, además de las silicificaciones de las estructuras biogénicas sin discernir, aparecen diferentes perforaciones rellenas, también silicificadas. Su característica más específica es que están más intensamente silicificadas que el substrato que las rodea y en ellas existen piritas, hematites, magnetita y glauconita, que no aparece en el resto del hardground. Esta asociación mineral indicaría un ambiente local dentro del relleno de la perforación, consecuencia de su relleno por limos ricos en materia orgánica. La detección de C por EDX en la magnetita podría indicar que se trata de magnetita biogénica. En el relleno tendría lugar un ambiente sulfato reductor consecuencia de la degradación de la materia orgánica y la presencia de Fe (Dickson et al., 2008). Este ambiente local es el que facilitó la silicificación más intensa.

\section{Conclusiones}

1. La gran abundancia de sílex en la Fm. Calizas de Oriñón, es debida a que en ella se producen varias circunstancias singulares como son: a) presencia constante de multitud de galerías de tipo Thalassinoides y otras estructuras biogénicas, b) una alta disponibilidad de sílice en el fluido intersticial del sedimento debido a la disolución/calcificación de las espículas silíceas incluidas en los sedimentos carbonáticos y c) existencia de un hardground regional, que favorece la formación de encostramientos. La silicificación preferente de todas las estructuras biogénicas es achacada a la presencia en ellas de materia orgánica, ya que esta ejerce un papel importante como fijador 
de la sílice, evitando así que se pierda en el fluido intersticial.

2. Las diferentes silicificaciones estudiadas revelan la influencia del tipo de bioturbación/estructura biogénica sobre los sílex resultantes. Los sílex más abundantes y fruto de una silicificación intensa, son los formados sobre Thalassinoides debido a que en el relleno de las galerías existe mayor proporción de materia orgánica y hay una alta porosidad y permeabilidad. La silicificación tuvo lugar durante la diagénesis temprana cuando la actividad bacteriana y la oxidación de la materia orgánica incluida en la galería está todavía activa.

3. Las morfologías filamentosas y cocoides, preservadas en las galerías silicificadas, son atribuidas a presencia microbiana (bacterias?). La silicificación temprana de estas galerías permitió su conservación.

4. En las galerías de Thalassinoides los procesos diagenéticos son específicos y diferentes a los de los sedimentos carbonáticos marinos que las incluyen. Después de la silicificación general opalina, hubo carbonatación con neoformación de calcita. La calcita neoformada se produciría en condiciones suboxidantes y con poca materia orgánica. El paso de condiciones oxidantes a condiciones disaeróbicas dentro de las galerías, se acompañaría con la aparición de microorganismos fermentantes. Los subproductos de estos organismos facilitarían la neoformación de dolomita en microambientes alcalinos y reductores con la presencia de sulfatos. Las fases opalinas iniciales se transformaron en cuarzo micro-criptocristalino y calcedonita durante la diagénesis temprana.

5. En las calizas que soportan el hardground además de las silicificaciones selectivas sobre fósiles (rostros de belemnites, ostreidos y equínidos), la sílice se acumula de forma importante en huellas de alimentación y rellenos de perforaciones, dando lugar a su vez a costras sobre estructuras de bioturbación y/o perforación que a pesar de su importancia no han podido ser clasificadas. Los sílex formados no presentan petrológicamente grandes diferencias mineralógicas con los de Thalassinoides, en relación a los minerales de la sílice aunque no sufren los procesos de carbonatación. Las perforaciones representan microambientes locales consecuencia de su relleno con limos y materia orgánica, originándose en ellas, además de silicificaciones intensas, minerales como pirita, hematites, magnetita y glauconita que indican un ambiente sulfato reductor consecuencia de la degradación de la materia orgánica y la presencia de Fe.

\section{AGRADECIMIENTOS}

Este trabajo ha sido financiado parcialmente por el proyecto de investigación CGL-2011-27826-CO2-02 del Ministerio de Economía y Competitividad. Los autores agradecen los comentarios y sugerencias realizados por la Dra. I. Rosales (IGME, Madrid) en el trabajo de campo, y por la Dra. M. RodríguezMartínez (Dpto. Estratigrafía, Facultad de Ciencias Geológicas, UCM), por sus indicaciones sobre las comunidades bentónicas microbianas. Asimismo agradecemos al Dr. P. Ruiz Ortiz y a la Dra. I. Rosales por las correcciones y aportaciones constructivas que han ayudado a mejorar este trabajo. Nuestro reconocimiento por su inestimable ayuda e interés a todo el personal técnico de los laboratorios de Geología del Museo Nacional de Ciencias Naturales: M. Castillejo (preparación muestras), R. Gonzalez (DRX), y L. Tormo, M. Furio y A. Jorge (laboratorio de "Técnicas No Destructivas", MEB, EDS, Micro-Raman).

\section{Referencias}

Aranburu, A. (1998). El Aptiense-Albiense de TrucíosGüeñes (oeste de Bizkaia).Tesis Doctoral, Universidad del País Vasco, 606 pp.

Baldermann, A.; Deditius, A.P.; Dietzel, M.; Fichtner, V.; Fischer, C.; Hippler, D.; Leis, A.; Baldermann, C.; Mavromatis, V.; Stickler, C.P. \& Strauss, H. (2015). The role of bacterial sulfate reduction during dolomite precipitation: Implications from Upper Jurassic platform carbonates. Chemical Geology, 412: 1-14. https://doi.org/10.1016/j. chemgeo.2015.07.020

Bąk, M.; Gorny, Z. \& Bąk, K. (2015). Sponge growth on the Cenomanian carbonate shelves of the Carpathian Basin: a record from spicule-rich turbidites. Bulletin of Geosciences, 90: 651-666. https://doi. org/10.3140/bull.geosci.1544

Bown, T.M. \& Kraus, M.J. (1983). Ichnofossils of the alluvial Willwood Formation (lower Eocene), Bighorn basin, northwest Wyoming, USA: Palaeogeography, Palaeoclimatology, Palaeoecology, 43: 95-128. https://doi.org/10.1016/0031-0182(83)90050-0

Buatois, L.A. \& Mángano, M.G. (2011). Ichnology: Organism-substrate interactions in space and time. Cambridge University Press, New York, 358 pp. https:// doi.org/10.1017/cbo9780511975622

Bromley, R.G. \& Ekdale, A.A. (1984). Trace Fossil Preservation in Flint in the European Chalk. Journal of Paleontology, 58: 298-311.

Bromley, R. G. \& Schönberg, C. H. L. (2008). Borings, bodies and ghosts: spicules of the endolithic sponge Aka akis sp. nov. within the boring Entobia cretacea, 
Cretaceous, England. In: Current Developments in Bioerosion. Erlangen Earth Conference Series, (Wisshak M. \&. Tapanila L., Eds.), Springer-Verlag, Berlin $1-12$.

Bustillo, M.A. (2010). Silicification of continental carbonates. En: Carbonates in Continental Settings: Processes, Facies and Applications (Alonso-Zarza A.M. \& Tanner L.H., Eds.). Developments in Sedimentology, 62: 153-174.

Bustillo, M.A. \& Ruiz Ortiz, P. (1987). Chert occurrences in carbonate turbidites: examples from the Upper Jurassic of the Betic Mountains (southern Spain). Sedimentology, 34: 611-621. https://doi. org/10.1111/j.1365-3091.1987.tb00790.x

Clayton, C. J. (1986). The chemical environment of flint formation in upper Cretaceous Chalks. In: The Scientific Study of flint and chert (Sieveking, G. de C. \& Hart, N.B. Eds.). Cambridge University Press, 43-54.

Corlett, H.J. \& Jones, B. (2012). Petrographic and Geochemical Contrasts between Calcite- and DolomiteFilled Burrows in the Middle Devonian Lonely Bay Formation, Northwest Territories, Canada: Implications for Dolomite Formation in Paleozoic Burrows. Journal of Sedimentary Research, 82: 648-663. https://doi.org/10.2110/jsr.2012.57

Dai, H.; Xing, L.; Marty, D.; Zhang, J.; Scott Persons IV, W.; Hu, H. \& Wang, F. (2015). Microbially-induced sedimentary wrinkle structures and possible impact of microbial mats for the enhanced preservation of dinosaur tracks from the Lower Cretaceous Jiaguan Formation near Qijiang (Chongqing, China). Cretaceous Research, 53: 98-109. https://doi. org/10.1016/j.cretres.2014.10.012

Dickson, J.A.D.; Wood, R.A.; Bu Al Rougha, H. \& Shebl, H. (2008). Sulphate reduction associated with hardgrounds: Lithification afterburn!. Sedimentary Geology, 205: 34-39. https://doi.org/10.1016/j. sedgeo.2008.01.005

Elorza, J. (1992). Geological characterization of the chert and its application to Archaeological research. En: The Late Quaternary in the Western Pyrenean Region. (Cearreta, A. \& Ugarte, F., Eds.). Servicio Editorial Universidad País-Vasco, 95-108.

Elorza, J. \& Bustillo, M.A. (1989). Early and late diagenetic chert in carbonate turbidites of the Senonian flysch, N.E. Bilbao. Spain. En: Siliceous Deposits of the Tethys and Pacific Regions. (Hein, J.R. and Obradovic, J., Eds). Springer-Verlag, New York, 93-105. https://doi.org/10.1007/978-1-4612-3494-4 7

Elorza, J. \& García-Garmilla, F. (1993). Chert appearance in the Cueva-Bedón carbonate platform (Upper Cretaceous, Northern Spain). Geological Magazine, 130: 805-816. https://doi.org/10.1017/ S0016756800023177

Elorza, J. \& García-Garmilla, F. (1997). Chert types in the Cueva carbonate platform (Upper Cretaceous,
Northern Spain). En: Siliceous Rocks and Culture. (Ramos-Millán A. \& Bustillo M.A., Eds.). Servicio Editorial Universidad de Granada. Serie monográfica de Arte y Arqueología, 42: 57-74.

Erkiaga, M.; García-Garmilla, F. \& Elorza, J. (1997). Modificaciones diagenéticas en nódulos de sílex por influencia de fluidos dolomitizantes: Ejemplos en el Cretácico superior de la Región Vasco-Cantábrica. Geogaceta, 22: 69-72.

Flor, G. \& Flor Blanco, G. (2014). Raised beaches in the Cantabrian coast. En: Landscapes and Landforms of Spain. Springer-Verlag, Netherlands, 239-248. https://doi.org/10.1007/978-94-017-8628-7_20

García-Garmilla, F. \& Elorza, J. (1996). Dolomitization and synsedimentary salt tectonic: The upper Cretaceous Cueva Formation at El Ribero, Northern Spain. Geological Magazine, 133: 721-737. https:// doi.org/10.1017/S0016756800024572

García-Ramos, J.C.; Valenzuela, M. \& Suarez de Centi, C. (1989). Sedimentología de las huellas de actividad orgánica. En: Sedimentología, Vol. II. (Arche, A. Ed.). Consejo Superior de Investigaciones Científicas: $261-342$.

Gingras, M.K.; Pemberton, S. G.; Muelenbachs, K. \& Machel, H. (2004). Conceptual models for burrow-related, selective dolomitization with textural and isotopic evidence from the Tyndall Stone, Canada. Geobiology, 2: 21-30. https://doi. org/10.1111/j.1472-4677.2004.00022.x

Herrero, J.M. (1989). Las mineralizaciones de $\mathrm{Zn}, \mathrm{Pb}$, $F$ en el sector occidental de Vizcaya: Mineralogía, Geoquímica y Metalogenia. Tesis Doctoral Universidad del País Vasco, 258 pp.

Knoll, A.H. (1985). Exceptional Preservation of Photosynthetic Organisms in Silicified Carbonates and Silicified Peats. Philosophical Transactions of the Royal Society of London, Series B, 311, No. 1148: 111-122. https://doi.org/10.1098/ rstb.1985.0143

Maliva, R. G. \& Siever, R. (1988). Diagenetic replacement controlled by force of crystallization. Geology, 16: 688-691. https://doi.org/10.1130/00917613(1988)016<0688:DRCBFO>2.3.CO;2

Maliva, R. G. \& Siever, R. (1989). Chertification histories of some Late Mesozoic and Middle Palaeozoic platform carbonates. Sedimentology, 36: 907-926. https://doi.org/10.1111/j.1365-3091.1989. tb01753.x

Mángano, M.G. \& Buatois, L.A. (1994). Trazas fósiles e icnofabricas en depósitos carbonáticos cretácicos, Las Cuevas, Alta Cordillera de Mendoza. Ameghiniana, 31: 55-66.

Mary, G. (1983). Evolución del margen costero de la Cordillera Cantábrica en Asturias desde el Mioceno. Trabajos de Geología, 13: 3-35.

McBride, E.F.; Abdel-Wahab, A. \& El-Younsy, A.M. (1999). Origin of spheroidal chert nodules, Drunka Formation 
(Lower Eocene), Egypt. Sedimentology, 46: 733-755. https://doi.org/10.1046/j.1365-3091.1999.00253.x

Mínguez, J.M. \& Elorza, J. (1994). Diagenetic volumenfor-volume replacement. Force of crystallization and depression of dissolution. Mineralogical Magazine, 58: 133-140. https://doi.org/10.1180/minmag. 1994.058.390.12

Mortimore, R. N. \& Pomerol, B. (1987). Correlation of the Upper Cretaceous White Chalk (Turonian to Campanian) in the Anglo-Paris Basin. Proceedings of the Geologists' Association, 98: 97-143.

Olivé Davó, A. \& Ramírez del Pozo, J. (1982). Mapa Geológico de España 1:50.000, hoja $n^{0} 36$, (Castro-Urdiales). IGME, Madrid.

Rosales, I. (1995). La Plataforma carbonatada de Castro Urdiales (Aptiene-Albiense, Cantabria). Tesis Doctoral, Universidad del País Vasco, 496 pp.

Rosales, I. (1999). Controls on carbonate-platform evolution on active fault blocks: The Lower Cretaceous Castro Urdiales Platform (Aptian-Albian, Northern Spain). Journal of Sedimentary Research, 69: 447465. https://doi.org/10.2110/jsr.69.447

Siever, R. (1962). Silica Solubility, $0^{\circ}-200^{\circ}$ C., and the Diagenesis of Siliceous Sediments. The Journal of Geology, 70: 127-150. https://doi.org/10.1086/626804

Tarriño, A. (2001). El sílex de la Cuenca Vasco Cantábrica y el Pirineo Navarro: caracterización y su aprovechamiento en la Prehistoria. Tesis Doctoral, Universidad del País Vasco, 384 pp.

Tarriño, A.; Elorrieta, I. \& García-Rojas, M. (2015). Flint as raw in prehistoric times: Cantabrian Mountain and Western Pyrenees data. Quaternary International, 364: 94-108.

Taylor, P.D. \& Wilson, M.A. (2003). Palaeoecology and evolution of marine hard substrate communities. Earth-Science Reviews, 62: 1-103. https://doi. org/10.1016/S0012-8252(02)00131-9

Zimmerle, W. (1991). Stratigraphic Distribution, Lithological Paragenesis, Depositional Environments and Diagenesis of Fossil Siliceous Sponges in Europe. En: Fossil and recent sponges. (Reitner, J. \& Keupp, H., Eds.) Springer, 554-577. https://doi. org/10.1007/978-3-642-75656-6_46

Zijlstra, H.J.P. (1987). Early diagenetic silica precipitation, in relation to redox boundaries and bacterial metabolism, in late cretaceous chalk of the Maastrichtian type locality. Geologie en Mijnbouw, 66: 343-355.

Zhang, F.; Xu, H.; Shelobolina, E.S.; Konishi, H.; Converse, B.; Shen, Z. \& Roden, E.E. (2015). The catalytic effect of bound extracellular polymeric substances excreted by anaerobic microorganisms on $\mathrm{Ca}-\mathrm{Mg}$ carbonate precipitation: Implications for the "dolomite problem". American Mineralogist, 100: 483-494. https://doi.org/10.2138/am-2015-4999 